\title{
CITIZENSHIP STATUS AND INHERITANCE OF ADOPTED CHILDREN CARRIED OUT BY SPOUSES OF FOREIGN NATIONALS IN INDONESIA
}

\author{
Indriani Putri Sofyanti Meliala ${ }^{*} \bowtie$ \\ ${ }^{{ }^{1} 1}$ Faculty of Law, Universitas Katolik Parahyangan, Indonesia
}

DOI: https://doi.org/10.29121/granthaalayah.v8.i12.2020.2683

Article Type: Research Article

Article Citation: Indriani Putri

Sofyanti Meliala. (2020).

CITIZENSHIP STATUS AND

INHERITANCE OF ADOPTED

CHILDREN CARRIED OUT BY

SPOUSES OF FOREIGN NATIONALS

IN INDONESIA. International

Journal of Research -

GRANTHAALAYAH, 8(12), 121-129.

https://doi.org/10.29121/granthaa

layah.v8.i12.2020.2683

Received Date: 03 December 2020

Accepted Date: 31 December 2020

Keywords:

Adoption of Children

Citizenship Status

Foreign Citizens

Inheritance

\section{ABSTRACT}

Children are a gift from God Almighty that is dreamed of by every couple. Couples who do not have offspring usually adopt children to continue their lineage and maintain their marriage. Appointment of children in Indonesia is the adoption of children between Indonesian citizens (domestic adoption) and the adoption of children by Foreign Citizens (Intercountry adoption). Requirements and procedures the appointment of an Indonesian citizen by a foreign national is explained in PP No. 54 of 2007 concerning Implementation of Child Appointment, Minister of Social Affairs Regulation No. 110 / HUK / 2009 Regarding the Requirements for Appointment of Children, the two regulations are inseparable from Law No. 35 of 2014 concerning Child Protection. The purpose of this study is to examine and determine the status of inheritance and legal consequences on the citizenship status of the process of adopting Indonesian Citizens' children by Foreign Citizens after a court ruling. The research method used is a normative juridical approach that is by focusing on data and field interviews to study primary, secondary, tertiary data collected in the form of traditional materials that are related to the problem under study which will then be analyzed in a qualitative juridical manner, then analyzed descriptively analytically to obtain a comprehensive and systematic picture of the problem under investigation connected with applicable legal regulations. The results showed that there were still many Indonesian citizens being adopted by foreign citizens who did not comply with the procedures. Problems that arise are regarding citizenship status and inheritance of adopted children. If the adopted child has a foreign nationality, he/she cannot obtain an estate with ownership status, but can only control the usage rights. This is stated in Article 21 of the Basic Agrarian Law.

\section{INTRODUCTION}

Article 1 paragraph (1) of Law Number 1 of 1974 concerning Marriage contains the purpose of marriage, namely forming a happy family or household. One of the elements of happiness in the family is the presence of children. Children as a continuation of the lineage and are part of the generation who play a significant role in determining the success of a nation. In reality, not all married couples can have children as expected because many factors can

(c) 2020 The Author(s). This is an open access article distributed under the terms of the Creative Commons Attribution License, which permits unrestricted use, distribution, and reproduction in any medium, provided the original author and source are credited. 
influence a husband and wife to have children as expected. Therefore, some efforts can be made by a married couple to have children, one of which is adoption (Djaja S. Meliala, 1992).

Adoption of children is not new in Indonesia, because since ancient times, adoption has been carried out in different ways and motivations, according to the legal system that is developing in the region concerned (Soedharyo Soimin, 2002). Indonesia has realized adoption of children by compiling a statutory regulation, namely Law no. 23 of 2002 concerning Child Protection which was amended again by Law no. 35 of 2014 concerning Child Protection, from now on referred to as the Law on Child Protection. Besides, it is also scattered in other statutory regulations such as the Minister of Social Affairs Regulation No.110 of 2009 concerning the Requirements for Adoption and the Government Regulation of the Republic of Indonesia Number 54 of 2007 concerning the Implementation of Adoption.

Adoption of children is a legal act because it must go through a legal process, and there is a judge's order in court. Adoption of children carried out by several pairs of husband and wife did not only come from orphans; some adopted children in the family. Due to this, there will be a legal relationship between adoptive parents and adopted children, the same as the relationship between parents and biological children. The number of adopted children is unlimited, according to one's ability to maintain and ensure the child's survival (Muderis Zaini, 1995). In general, every child has rights and obligations as a child in a family, but children's rights are often neglected due to difficult family conditions. Based on this it also causes the child to be adopted by the adoptive parents, sometimes the requests of the child are not fulfilled, such as the inheritance problem between the biological parents and the adopted child and the child's citizenship status. As stated in the Law on Child Protection, adoption by adoptive parents does not break the child's relationship with his biological parents.

In 1979 there was a Supreme Court Circular (SEMA) dated April 7, 1979 Number 2 of 1979 concerning Adoption of Children. Based on the SEMA, the Ratification of the Adoption of Indonesian Citizen Children can only be carried out using order at the District Court, and it is not justified if the adoption of the child is carried out with a notary deed legalized by the District Court. Thus, every case of adoption must go through a District Court Decision. Minister of Social Affairs Regulation No. 110 / HUK / 2009 concerning Requirements for Adoption of Children, Article 1 point (4) explains the meaning of prospective adoptive parents, namely people who apply to become Adoptive Parents. Prospective adoptive parents referred to in the Domestic Adoption are husband and wife Indonesian citizens, and widows with Indonesian citizenship status (Article 18 of the Minister of Social Affairs 101 of 2009). Prospective adoptive parents referred to in Intercountry Adoption are Foreign Citizens with Foreign Citizens, Indonesian Citizens whose spouse is a Foreigner, and Indonesian Citizens who adopt a coming child from a Foreign Citizen (CHAPTER VI and CHAPTER VII Permensos 101 Years 2009) (M. Budiarto, 1985).

The adoption that occurs is not only limited to Indonesian citizens. Many Indonesian citizens adopt foreign children and vice versa. Adoption between countries is not as simple as adoption between citizens, which can result in the transfer of the nationality of the child adopted following the race of the adoptive parents. The European Convention on the Adoption of Children in 1965 (European Convention on the adoption of children), among other things, stipulates implicitly that inter-state adoption is considered legal or legal if it is carried out in front of a District Court and obtains a Stipulation (Ahmad Kamil and M. Fauzan, 2008).

To regulate the adoption of children between countries, the Circular of the Director-General of Law and Legislation No. JHA.1 / 1/2 dated 24 February 1978 and Law No.12 of 2006 concerning amendments to Law no. 62 of 1958 concerning Citizenship of the Republic of Indonesia which in essence states that the adoption of Indonesian citizens by foreigners can only be carried out employing a District Court ruling. This legal pluralism regarding adoption continues today. Until now, no law regulates the adoption of children explicitly. To complement the existing rules and to curb the practice of adoption, policy regulations were issued in the form of Government Regulations, Decrees of the Minister of Social Affairs and management of judicial institutions such as Circular of the Supreme Court. Some are contained in laws regulating certain matters such as in The Citizenship Law, the Child Welfare Law and the Child Protection Law.

The reality that occurs in Indonesia, especially in big cities such as Jakarta and Bandung, is that the adoption of many children is not following what has been determined by laws and regulations. In particular, the adoption of children by foreign nationals must be carried out through a court ruling or decision. The adoption of a child made by a foreign national partner only through childcare institutions and a certificate made by a notary. This has led to rampant legal cases occurring in children who have been adopted by their adoptive parents without going through a court order. 
Even though until now there has been no law that explicitly discusses adoption, it is hoped that there will be laws and regulations that clearly state that adoption of children by foreign nationals must go through a court ruling or decision. The Indonesian state is expected to be able to enforce the legal arrangements that have been made and embodied in the Child Protection Law to provide legal protection for Indonesian children who are adopted by their adoptive parents, especially those with foreign nationalities.

This study aims to understand and determine the inheritance status of adopted children by foreign nationals and to study and formulate the legal consequences for the nationality of adopted children. The problem identification is limited to whether the inherited assets of the biological parents of children who have been adopted by foreign nationals can still be transferred after the adopted child becomes a foreign national. And how is the legal effect on the citizenship status of the child adopted by the Foreign Citizen Pairs related to Law No.12 of 2006 concerning Citizenship of the Republic of Indonesia.

\section{METHOD}

The research was conducted using the "normative juridical approach method", a namely legal study conducted on legal principles and secondary data or literature through a traditional positive inventory (Soerjono Soekanto and Sri Mamudji, 2003). The normative juridical methods that will be carried out in this legal research are positive legal inventory research, legal principles research, and legal research that examines the systematics of statutory regulations (Amirudin and Zainal Asikin, 2010). The research stage is carried out in two phases, and the first stage is library research which contains primary legal materials, namely binding traditional materials in the form of statutory regulations, among others; Law No. 4/1979 on Child Welfare, Law No. 54/2007 on the Implementation of Adoption, Law No. 35 of 2014 concerning Child Protection, Law Number 12 of 2006 concerning Citizenship of the Republic of Indonesia, Law Number 5 of 1960 concerning Basic Agrarian Principles and Regulation of the Minister of Social Affairs No.110 of 2009 concerning Requirements for Adoption of Children. Secondary legal materials, namely research carried out by examining scientific books, journals, reports, scientific papers, undergraduate research results, and other materials related to the problems to be studied, namely in the field of Family Law. And tertiary legal materials, namely reference materials such as encyclopedias, dictionaries, both translation and standard dictionaries, magazines or newspapers that add to the understanding related to the object of research. The second stage is field research which aims to obtain primary data for material collection using interviews with sources so that relevant data can be obtained in practice in connection with research on adoption conducted by foreign national pairs. The data collection technique used is the literature study, which is carried out by collecting data from statutory regulations, literature studies, and library documents to obtain secondary legal material. As well as interviews conducted by the author with several sources, such as judges or court clerks who can provide direct information about the adoption of children, as well as childcare institutions to obtain primary data related to the adoption of children by foreign nationals. The research specification was carried out in a descriptive-analytical manner, to describe the "rules" and "legal theory" related to the regulation of adoption logically and systematically using data analysis methods which were carried out in a qualitative juridical manner to answer problem identification by studying, understanding, analyzing and solving problems by sticking to scientific studies (Soerjono Soekanto, 1986).

\section{RESULTS AND DISCUSSIONS}

\subsection{TRANSFER OF INHERITANCE OF BIOLOGICAL PARENTS TO CHILDREN WHO HAVE BEEN ADOPTED BY FOREIGN NATIONALS AND BECOME FOREIGN CITIZENS}

Adoption of children results in several legal consequences for adopted children, one of which is inheritance. In customary law, adoption results in a break in the civil relationship between the adopted child and the biological parents and the position of the adopted child are equalized to the biological child by the adoptive parent, so that if the adoptive parent dies, the adopted child has the right to inherit the assets of the adoptive parent. (Tamakarin S, 1987). Unlike Islamic law, because the term adoption is not known, it is only known as guardianship, the relationship between the child and the child's biological parents is not broken, likewise with statutory regulations as stated in 
Article 39 paragraph (2) of Law 35 of 2014 concerning Child Protection which explicitly states that adoption of children by adoptive parents does not sever the child's relationship with their biological parents.

In terms of adoption, adoption of adopted children as adoptive families comes not only from adoptive families but also from the local community (J. Satrio, 2000) In practice adoption can be classified into 2 (two) types, namely: 1) Adoption Plena, namely the adoption of comprehensive and profound legal consequences. The adopted child breaks the legal relationship with his biological parents and continues the legal relationship with the adoptive parent. As a result of the law, the child has inheritance rights from his adoptive parents and no longer has inheritance rights from his biological parents; 2) Adoption Minus Plena, namely adoption that is not so deep and comprehensive due to the law. So here it is only for maintenance so that by itself does not create inheritance rights from the adoptive parents. Indonesia itself is a country that adheres to the principle of adoption minus plena (Sudargo Gautama, 1981).

The legal treasures in Indonesia, both customary law, Islamic law and national law, have provisions regarding inheritance rights. Depending on what direction will be used, it means that a person can choose which law will be used to determine the inheritance of adopted children. The following is a description of the inheritance rights of adopted children in terms of customary law, Islamic law and national law.

\subsubsection{CUSTOMARY LAW}

When using a traditional institution, the determination of inheritance for adopted children depends on the applicable customary law. For parental families, Java, for example, adoption does not automatically break the family ties between the child and the biological parents. Therefore, apart from obtaining inheritance rights from his adoptive parents, he is also still entitled to an inheritance from his birth parents. Unlike in Bali, adoption is a legal obligation that releases the child from the original family into the adoptive family. The child becomes the biological child of the adoptive father and continues the position of the adoptive father. So that the legal relationship between the adopted child and his birth parents is severed and the adopted child is no longer inheriting from his birth parents.

\subsubsection{ISLAMIC LAW}

In Islamic law, adoption does not have legal consequences in terms of blood relations, guardian-guardianship and inheritance relationships with adoptive parents. He remains the heir of his biological parents, and the child continues to use the name of his biological father.

\subsubsection{LEGISLATION}

In the laws and regulations in Indonesia, inheritance is known in the Civil Code, but there is no known inheritance for adopted children. The inheritance problem is known in Staatblaad 1917 No. 129 but even that was only for the Foreign Orientals and Chinese. In Staatblaad 1917 No. 129 the legal consequence of adoption is that the child legally acquires the name of the adoptive father, becomes the child born from the marriage of the adoptive parents and becomes the heir of the adoptive parents. That is, as a result of the appointment, all civil relations are cut off, which originates from the offspring by birth, namely between the biological parents and the child.

According to Staatblad in 1917, the problems resulting from the law of adoption are regulated in Articles 11, 12, 13, and 14 of Staatblaad 1717, the following are the main descriptions of some of these articles: Article 11 states that adoption carries a legal consequence that the person who is appointed if he has another lineage name, changes to the name of the descendant of the person who adopted him as a substitute for the name of the descendant of the person who was appointed automatically to the biological child of the birth parent who adopted him or his adoptive mother, and automatically disconnected from the lineage of the birth parent,

Suppose the legal position of the adopted child has been equalized with the biological child of the adoptive parent. In that case, the adopted child must obtain rights similar to the rights acquired by the biological child of the adoptive parent. Adopted children have inheritance rights such as full inheritance rights for biological children which can close the inheritance rights of siblings and also biological parents of adoptive parents (Bismar Siregar, 1986). In practice, if a foreign citizen will adopt an Indonesian citizen, the law that will be enforced is the national law which refers to the directions on adoption. As stated in article 39 of Law no. 35 of 2014 reads as follows: 
1) Adoption can only be carried out in the best interests of the child and is carried out based on local customs and the provisions of the applicable laws and regulations

2) Adoption does not break the blood relationship between the adopted child and the biological parents

3) 3). The candidate adoptive parents must share the same religion as the adopted child candidate

4) Adoption of children by foreign nationals may only be undertaken as a last resort

5) If the child's origin is not known, the child's religion is adjusted to the faith of the majority of the local population

6) Adoptive parents are obliged to notify their origins and biological parents by taking into account the readiness of the child concerned.

From the text of the article above, it can be concluded that adoption of children carried out by custom or court rulings is not allowed to separate the blood relationship between adopted children and their biological parents, which aims, among other things, to prevent the possibility of inbreeding. Therefore, to avoid things that are undesirable to adopted children, adoptive parents are obliged to notify the origin and biological parents of adopted children by considering the child's mental readiness.

However, in reality, many cases occur after foreign citizens adopt Indonesian citizens. Then the children are taken to the country of origin of their adoptive parents, which in the end the civil relations between the children and their biological parents are severed. Such things should be avoided. If this has already happened, the adopted child will be responsible for the loss, and indirectly his rights will be neglected, such as the right to inherit from his biological parents. Especially if one day it turns out that the adoptive parents have offspring, the adopted child may be neglected.

Adoption is changing the status of the child to become a legal biological child with all its rights and obligations. Where before the adoption implementation, prospective adoptive parents have passed the selection stage with strict requirements. This is so that the welfare of the child can be guaranteed. It cannot be denied that even though in some cases, there is a discrepancy in the implementation, many children who have been adopted by adoptive parents are cut off from their biological parents. Because in reality there are many adoptions of children that do not go through court rulings and the conditions that have been regulated are neglected and are not implemented, this is what ultimately hurts the children in the future.

Adoption of children carried out by foreign nationals of children of Indonesian citizens must go through a predetermined procedure and obtain a court decision. After the verdict is granted, the child's care and responsibility have entirely shifted to the adoptive parents. After that, the child can be said to have become the legal child of the foreigner who adopted it. In general, foreign partners who adopt Indonesian citizens will stay and live in Indonesia for a long time. Still, it is not uncommon for foreign nationals to return to their country and bring their adopted child to live and settle in their country of origin.

When a child adopted by a foreign national partner receives a court decision, the nationality of the child will automatically become double, or in other words, the race of the adopted child is an Indonesian citizen and also a foreigner (according to the country of origin of the adoptive parents). After the child turns 18 years old, he must choose his nationality. If the child chooses an alien race like his adoptive parents, then he is no longer an Indonesian citizen.

When the adopted child has grown up and has chosen his citizenship, he will only have one nationality, either becoming a foreign citizen or returning to Indonesian citizenship. If one day, the adoptive parent dies, and the inheritance right only falls to the adopted child, the adopted child will receive the legacy that has been left by the adoptive parents. Likewise, suppose the biological parent of the adopted child dies. In that case, even though the adopted child has a foreign nationality, he is still entitled to inherit from the inheritance of the birth parents.

There is no problem with citizenship status and inheritance if the child adopted by a foreign citizen then chooses citizenship to become an Indonesian citizen, because if one day his biological parents die, he will get an inheritance left by his parents, whether in the form of land or buildings. Who is in Indonesia will be able to have it? The problem is if the adopted child then becomes a foreign national. In the Civil Code, the term inheritance is known and regulated, but the term adopted child is not known. So, it can be said that if the adopted child has a foreign nationality. He/she has inherited property left by his biological parents who are in Indonesia. The law regulating inheritance is a provision regarding an estate that is in the laws and regulations in Indonesia, and these rules are contained in Article 21 Law Number 5 the Year 1960 concerning Basic Agrarian Regulations, namely:

1) Only Indonesian citizens can have property rights.

International Journal of Research -GRANTHAALAYAH 
2) The government determines legal entities which can have property rights and its conditions.

3) Foreigners who after the enactment of this law obtain property rights due to inheritance without a will or mixing of assets due to marriage, likewise Indonesian citizens who have property rights and after this law comes into effect lose their citizenship are obliged to relinquish this right within one year from the acquisition of said right or loss of citizenship. If after this period has passed, the right of ownership is released, then the request is cancelled because the law and the landfall on the State, provided that the rights of the other party that impose it continue.

4) As long as a person besides his Indonesian citizenship has foreign citizenship, he cannot own land with ownership rights. For him, the provisions in paragraph (3) of this article apply.

So, it can be said, if the child gets an inheritance that has been left by his biological parents who are in Indonesia, then the property does fall to the heir, in this case, the adopted child. But foreigners cannot have the right to ownership of an object (land and buildings) in Indonesia, but can only obtain the right to use (HP) only.

Thus, it is not allowed for foreign citizens to own land and buildings with the status of property rights (HM). This has been further regulated in Law Number 5 of 1960 concerning Basic Agrarian Principles. Article 9 UUPA states that only Indonesian citizens can have a full relationship with the earth, water and air space of Indonesia. In his explanation, it was noted that only Indonesian citizens could have ownership rights over land. Property rights by foreigners are prohibited from Article 26 paragraph (2) of the UUPA, and violations of this article are subject to "null and void" sanctions. Then the land will fall to the State.

However, it does not eliminate the opportunity for foreign citizens to have rights to land or buildings in Indonesia, mostly if it is inherited property. In Article 26 (paragraph 2) of the UUPA, it is said that giving with a will and other actions intended to directly or indirectly transfer property rights to a foreigner, to a citizen who besides Indonesian citizenship has foreign citizenship, is null and void because of the law and landfall. To the State. However, the government has also issued PP No. 41/1996 which regulates the ownership of a residential or residential house by foreigners, but on condition that the foreigner lives and is domiciled in Indonesia.

If the foreigner lives outside Indonesia, his inheritance if it is in the form of land or a building which is located in the territory of Indonesia, the ownership status is only as use right. And if one day the adoptive parent dies, the adopted child will also receive an inheritance from the adoptive parents, because the adopted child has been treated like a biological child for part of the legacy of the adoptive parents.

The legal consequences that arise with the regular events of the death of the adoptive parents are the problem of how to maintain and continue the rights and obligations of the adoptive parents who died. The settlement of these rights and responsibilities is regulated by inheritance law (Eman Suparman, 2007). Inheritance law contains provisions governing the method of transferring and transferring assets (tangible or intangible) from the heirs to their heirs (Hilman Hadikusuma, 2003).

As it is known that the issue of adoption is not regulated in the Civil Code. In the Civil Code, only the recognition of children outside of marriage is held, namely as contained in the book I Chapter XII-part III Article 280 to Article 289 of the Civil Code. Recognition of children as occurs in practice in society and the world of justice today is not only limited to the glory of children outside of marriage but includes recognition of children in a broad sense (Soeroso, 2007).

In Islamic law, adoption does not have legal consequences for guardianship and inheritance on adoptive parents. He remains the heir of the biological parents, and the child continues to use the name of the biological father (Article $171 \mathrm{~h}$ jo Article 209 Compilation of Islamic Law). Adopted children who are not adopted through the procedures and procedures for adoption as stipulated and there is no court decision, so the child is not legally valid and does not inherit from the adoptive parents. He will only inherit if his adoptive parents make a will which is assigned to him.

In terms of the guardianship, adoptive parents only have the right to care for the child (foster child) which is responsible for the cost of education, health and other needs. Unlike Islamic Law, according to Customary Law and Supreme Court Jurisprudence (statutory regulations), the position of an adopted child is the same as a biological child. Adopted children inherit from their adoptive parents, except for inheritance. The heirlooms return to the heirs of blood descent.

If linked to cases as described in the previous chapter, the two examples of issues raised have similarities, namely that children adopted by foreign nationals are Protestant Christians like their adoptive parents, and the child is appointed based on statutory regulations. So, the law of inheritance is used based on statutory regulations. That the adopted child will get his share if the adoptive parent dies later, on the other hand, if the biological parent dies, 
Indriani Putri Sofyanti Meliala

the child will also be entitled to inherit from the inheritance of the parent even though he/she is a foreign citizen. Suppose the legacy left by his biological parents in Indonesia is in the form of land and other tangible objects. In that case, the control of the item will be transferred to the adopted child, but he does not have ownership rights over the ownership of the thing because he has become a foreign citizen.

\subsection{LEGAL CONSEQUENCES FOR THE CITIZENSHIP STATUS OF CHILDREN AFTER BEING ADOPTED BY A FOREIGN SPOUSE RELATED TO LAW N0.12 OF 2006 CONCERNING CITIZENSHIP OF THE REPUBLIC OF INDONESIA}

Adoption cannot be separated from the kinship between parents and children, considering that adoption is to divert a child from the sphere of authority of the family of the legal parent or legal guardian or another person who is responsible for the care, education and raising of the child into the family. The sphere of power of the foster parents' family based on a decision or decision of the district court. There are various kinds of legal systems regarding adoption that are followed by each country. They differ not only in terms of their requirements but also in their legal consequences. Some countries have stringent requirements for adoption and vice versa that have simple needs.

Heavy requirements can have far-reaching legal consequences because the kinship between the biological parents and the adopted child breaks up and then creates a legal relationship with the adoptive parents, with the result that the rights to provide for the child and education is the responsibility of the adoptive parents (Darwin Prinst, 2003). In the case of adoption of Indonesian Citizen (WNI) children by foreign citizens (WNA) towards citizenship, it adheres to the patrilineal principle, namely according to the citizenship law.

If the two adoptive parents are not of the same nationality (mixed marriage), the husband's citizenship law is still applied. In the case of mixed marriages, a problem that is vulnerable and often arises is the problem of the nationality of the child. The old citizenship law adheres to the principle of single citizenship, which in the law stipulates that what must be followed is the nationality of the father. This arrangement creates problems if the parents' marriage breaks up later.

In practice, the adoption of Indonesian citizens by foreign citizens (Intercountry adoption) has consequences for changing the child's citizenship status. When referring to Law Number 12 of 2006 concerning Citizenship of the Republic of Indonesia, which in Article 5 paragraph (2) of Law No.12 of 2006, reads, Indonesian Citizen Children who are not yet 5 (five) years old are legally appointed by citizens. Foreign countries based on the Court's decision are still recognized as Indonesian citizens. This indicates that the Indonesian government continues to prioritize adopted children to retain citizenship.

As stipulated in Article 6, if the child has dual citizenship in his / her nationality status, the child can state that he chooses one of his nationalities, the statement of selecting one of his races is stated in writing and submitted to the office by attaching the documents as stipulated in statutory regulations and submitted within 3 (three) years at the latest after the child turns 18 (eighteen) years old or already married.

Previously, Article 17 letter d of the Citizenship Law No. 62 of 1958, stipulates a child who is legally adopted by a foreigner as a child if the child concerned is not yet 5 (five) years old and by losing the citizenship of the Republic of Indonesia does not become stateless.

Whereas in Article 6 of Law No.12 of 2006 concerning Citizenship, it stipulates that in terms of the citizenship status of the Republic of Indonesia for children, among others in Article 5 and Article 21 paragraph (2), the result is that the child has dual nationality, after turning 18 (eighteen) years of age or already married, the child must declare choosing one of his races. When examined from the point of view of international civil law, dual citizenship also has potential problems, for example in terms of determining personal status based on the principle of nationality, a child is subject to the provisions of his nation-state. If the conditions between one state law are not contradictory, then there is no problem. Still, what if there is a conflict between one state law and another, then the regulation of the child's status will follow which country's rules. Then what if one provision violates the principle of public order in the conditions of another country.

In the case described in the previous chapter, the child adopted by a foreign national has been born and raised in the territory of Indonesia and born from a legally valid marriage. According to Law No.12 of 2006 concerning Citizenship, article (4) letter B, which reads "Indonesian citizens are children born from a legal marriage from a father and mother who are Indonesian citizens." Then the adopted child has Indonesian citizenship since birth 
because a foreign national adoptive parent adopted him, the child automatically has dual citizenship which he also gets from his adoptive parents. However, the child is obliged to choose his nationality when he is 18 years old. This is so that there are no problems and overlaps with the nationality status of the child.

From the description above, a common thread can be drawn that Indonesia prioritizes children's rights in its citizenship rights. In the case of adoption of children of Indonesian citizens by foreign citizens, it is avoided that children without citizenship, through the citizenship law mentioned above, it is seen that Indonesia is striving for children to continue to have citizenship.

\section{CONCLUSION}

In the implementation of the practice of adopting Indonesian citizens by foreign citizens in Indonesia, there are still many irregularities that are not following the procedures and procedures for the adoption process as stated in the laws and regulations regarding the process of implementing adoption. This has fatal consequences for children who are adopted at a later date and has an impact on their citizenship status and inheritance problems. If the adopted child then chooses to have a foreign nationality, then the child cannot obtain ownership rights to what is inherited by his biological parents in Indonesia, because he has an alien race (Article 21 of the Basic Agrarian Law). Although the inheritance property continues to be transferred to the child, it is only in the form of use rights if the inheritance is in the form of land or buildings. On the other hand, however, there is no problem regarding heritage and citizenship if the child chooses to become an Indonesian citizen. The citizenship status of a child is given when he is born. Then the child will become a citizen of the same country as his parents. However, in practice, the adoption of children of Indonesian citizens by foreign nationals has consequences for changing the child's citizenship status. The rules regarding citizenship have been stated in Law Number 12 of 2006 concerning Citizenship, Article 6 of the Law stipulates that if a child has dual nationality, the child can declare to choose one of his races after the child turns 18 years of age.

\section{SOURCES OF FUNDING}

This research received no specific grant from any funding agency in the public, commercial, or not-for-profit sectors.

\section{CONFLICT OF INTEREST}

The author have declared that no competing interests exist.

\section{ACKNOWLEDGMENT}

None.

\section{REFERENCES}

[1] Abdul Kadir Muhammad, Perkembangan Hukum Keluarga di Beberapa Negara Eropa, cet II, Bandung: Citra Aditya Bhakti, 2000.

[2] Ahmad Kamil, M.Fauzan, Hukum Perlindungan dan Pengangkatan Anak di Indonesia, Jakarta: Raja Grafindo Persada, 2008.

[3] Amirudin dan Zainal Asikin, Pengantar Metode Penelitian Hukum, Jakarta, PT. Raja Grafindo Persada, 2010.

[4] Andi Syamsu Alam, M. Fauzan, Hukum Pengangkatan Anak Perspektif Islam, Cet I, Jakarta: Kencana, 2008.

[5] B Bastian Tafal, Pengangkatan Anak Menurut Hukum Adat serta Akibat-Akibat Hukumnya Dikemudian Hari, Jakarta: Rajawali, 1983.

[6] Bismar Siregar, dkk, Hukum dan Hak-Hak Anak, Jakarta, Cv Rajawali, 1986

[7] Bushar Muhammad, Pokok-Pokok Hukum Adat, Jakarta: Pradnya Paramita, 1981.

[8] B. Ter Haar, Adat law in Indonesia, Terjemahan Hoebel, E Adamson dan A. Arthur Schiler, Jakarta, 1962.

[9] Djaja S.Meliala, Hukum Perdata Dalam Perspektif BW, Bandung: Nuansa Aulia, 2014. 
[10] Djaja S.Meliala, Pengangkatan Anak (Adopsi) di Indonesia, Bandung: Tarsito, 1992.

[11] Djaja S.Meliala, Pengangkatan Anak (Adopsi) Berdasarkan Adat Kebiasaan Setempat dan Peraturan Perundangan di Indonesia, Bandung: Nuansa Aulia, 2016.

[12] Eman Suparman, Hukum Waris Indonesia Dalam Perspektif Islam, Adat, dan BW, Bandung: Refika Aditama, Jakarta, 2007.

[13] Fauzan, Pengangkatan Anak Bagi Keluarga Muslim Wewenang Absolute Peradilan agama, Majalah Mimbar Hukum, Jakarta, Edisi Desember 1999.

[14] Hadi Setia Tunggal, Konvensi Hak-Hak Anak (convention on the rights of the child), Jakarta: Harvarindo, 2000.

[15] Hilman Hadi Kusuma, Hukum Perkawinan Adat, cet 4, Bandung: PT. Citra Aditya Bhakti, 1991.

[16] Hilman Hadi Kusuma, Hukum Waris Adat, Bandung: Citra Aditya Bakti, 2003.

[17] J. Satrio, Hukum Keluarga Tentang Kedudukan Anak Dalam Keluarga, Bandung: Sumur Bandung, 2000.

[18] Kamil A, Fauzan.HM, Hukum Perlindungan dan Pengangkatan Anak di Indonesia, Jakarta: Rajawali Press, 2010.

[19] Lulik Djatikumoro, Hukum Pengangkatan Anak di Indonesia, Bandung: PT. Citra Aditya Bakti, 2011

[20] Muderis Zaini, Adopsi suatu Tinjauan Dari Tiga Sistem Hukum (cet. Ke 3), Jakarta: Sinar Grafika, 1995.

[21] Muhammad Jawad Mughniyah, Fiqih Lima Mazhab, Jilid II, Jakarta: Basri Press, 1992.

[22] Mustofa Hasan, Pengantar Hukum Keluarga, Bandung: Pustaka Setia, 2011.

[23] Purwadarminta, Kamus Umum Bahasa Indonesia, Jakarta: Balai Pustaka, 1976.

[24] Rahmadi Usman, Aspek-Aspek Hukum Perorangan dan Kekeluargaan di Indonesia, Jakarta: Sinar Grafika, 2006.

[25] Rika Saraswati, Hukum Perlindungan Anak Di Indonesia, Bandung: Citra Aditya Bakti, 2009.

[26] R. Soepomo, Bab-Bab Tentang Hukum Adat, Jakarta: Pradnya Paramita, 2007.

[27] Satrio, Hukum Keluarga Tentang Kedudukan Anak Dalam Undang-Undang, Bandung: Citra Aditya Bakti, 2005.

[28] Shanty Dellyana, Wanita dan Anak di Mata Hukum, Yogyakarta: Liberty, 2004.

[29] Soedharyo Soimin, Himpunan Dasar Hukum Pengangkatan Anak, (cet. Ke-2), Jakarta: Sinar Grafika, 2004.

[30] Soedharyo Soimin, Hukum Orang dan Keluarga, Jakarta: Sinar Grafika, 2002.

[31] Soerjono Soekanto, Intisari Hukum Keluarga, Bandung: Alumni, 1980.

[32] Soerjono Soekanto, dan Sri Mamudji, Penelitian Hukum Normatif, Jakarta: Raja Grafindo Persada, 2003.

[33] Soeroso, Perbandingan Hukum Perdata, Sinar Grafika, Jakarta, 2007.

[34] Sudarsono, Hukum Perkawinan Nasional, Jakarta: Rineka Cipta, 1991.

[35] Sudarsono, Kamus Hukum, Jakarta: 1992.

[36] Sudargo Gautama, Hukum Perdata Internasional Indonesia, Jilid III Bagian I, Buku ke-7, Bandung: Alumni, 1995.

[37] Sudargo Gautama, Soal-soal Aktual Hukum Perdata Internasional, Bandung: Alumni, Jilid 2, 1981.

[38] Surojo Wignjodipuro, Pengantar dan Azas-azas Hukum Adat, cet II, Bandung: Alumni, 1973.

[39] Tamakarin S, Asas-Asas Hukum Waris Menurut Tiga Sistem Hukum, CV. Pionir Jaya, Bandung, 1987.

[40] Wirjono Prodjodikoro, Hukum Warisan di Indonesia, Bandung: Sumur Bandung, 1991. 